\title{
Prevalence and infection intensity of the ovarian parasite Marteilioides chungmuensis during an annual reproductive cycle of the oyster Crassostrea gigas
}

\author{
Thao T. T. Ngo ${ }^{1}$, Franck C. J. Berthe ${ }^{2}$, Kwang-Sik Choi ${ }^{1, *}$ \\ ${ }^{1}$ School of Applied Marine Science, College of Ocean Science, Cheju National University, 1 Ara 1- Dong, Jeju, \\ Jeju-do 690-756, Korea \\ ${ }^{2}$ IFREMER, Laboratoire de Genetique et Pathologie, BP 133, 17390 La Tremblade, France
}

\begin{abstract}
The occurrence of Marteilioides chungmuensis, a protozoan paramyxean parasite in the reproductive system of the Pacific oyster Crassostrea gigas, was observed at Gosung Bay, Korea. Seasonal variation in gonad development was investigated in a suspended cultured oyster population. Gametogenesis began in February and first-spawning was observed between mid and late June when surface water temperature reached 22 to $25^{\circ} \mathrm{C}$. Spawning activity extended from mid June to late September, with 2 marked spawning peaks in June and August. Histological examination indicated that gonad development paralleled seasonal fluctuations in water temperature. Spawning in late June was partly associated with a sudden drop in salinity due to large freshwater inputs to the Bay with the summer monsoon. M. chungmuensis occurred in developing and fully mature eggs of spawning oysters in late June to January, but were not observed from February to May. Monthly mean infection intensity was high in late June when most oysters had their first spawning period. The infection level was also relatively high in late August and November, when oysters were spawning or had completed spawning. Several oysters collected in November (11.4\%) and December (16.3\%) carried a large quantity of ripe but $M$. chungmuensis-infected eggs, suggesting that infection also causes spawning failure by delaying spawning and destroying ripe oocytes.
\end{abstract}

KEY WORDS: Crassostrea gigas · Gonad development · Marteilioides chungmuensis · Ovary parasite $\cdot$ Korea

Resale or republication not permitted without written consent of the publisher

\section{INTRODUCTION}

The Pacific oyster Crassostrea gigas is one of the most important commercial species supporting the Korean fisheries industry. In Korea, oyster culture uses naturally available spat as seeds; these are collected during summer on spat collectors made of oyster shells attached to a plastic string, 4 to $6 \mathrm{~m}$ long. The seeds that settle on the oyster shells are then hung on a longline suspended in the water column by numerous buoys for growing out. For successful seed production and ultimately oyster production, studies on seasonal changes in gonadal maturation and impacts of envi- ronmental parameters on reproduction are essential for the Korean oyster industry. Over 170000 metric tonnes of oysters were produced in Korea in the year 2000 from the intensive suspended longline culture system, making Korea one of the world's largest oyster exporters (Ventilla 1984, FAO 1999).

Oyster landings in Korea have declined over the past decade. Several theories have been proposed to explain the decrease in oyster production, such as slow growth in highly intensive culture systems (Kang et al. 2000, Oh et al. 2002) and an insufficient supply of healthy seed oysters (Park et al. 1999a,b). The current decline may also be due to the effects of pollution and 
outbreaks of pathogenic infection along oyster culture grounds (Park \& Chun 1989, Choi et al. 1997).

Protozoan parasites in the phylum Paramyxea have been extensively studied in areas in which oysters and mussels are commercially raised (Becker \& Pauley 1968, Wolf 1977, Figueras \& Montes 1988, Villalba et al. 1993, Fuentes et al. 1995, Renault et al. 1995, Camacho et al. 1997, Berthe et al. 2000, Hine \& Thorne 2000). The presence of the ovarian parasite Marteilioides chungmuensis (Comps et al. 1986) has been reported from oyster culture grounds in Korea (Chun 1970, 1972, 1979) and in Japan (Imai et al. 1968, Matsusato \& Masumura 1981). Chun (1970, $1972,1979)$ initially reported the occurrence and pathologic features of an unidentified amoeba-like pathogen in the gonad of oysters collected along the south coast of Korea. Later, the ameboid pathogen was named $M$. chungmuensis nov. gen, nov. sp. by Comps et al. (1986, 1987). M. chungmuensis-infected Pacific oysters develop lumps or nodule-like gonads during the spawning season. Such infected oysters, with their abnormal appearance, are unacceptable on the market, resulting in serious economic losses to oyster farmers. Microscopic examination of infected oysters reveals that $M$. chungmuensis are mostly distributed inside the ovary, within the oocytes. Anderson \& Lester (1992) have also reported a second species of the genus, M. branchialis, from Sydney rock oysters Saccostrea commercialis. More recently, Lee et al. (2001) also reported a Marteilioides-like organism from Tapes philippinarum distributed along the southern coast of Korea, although its impacts on the clam industry are unknown.

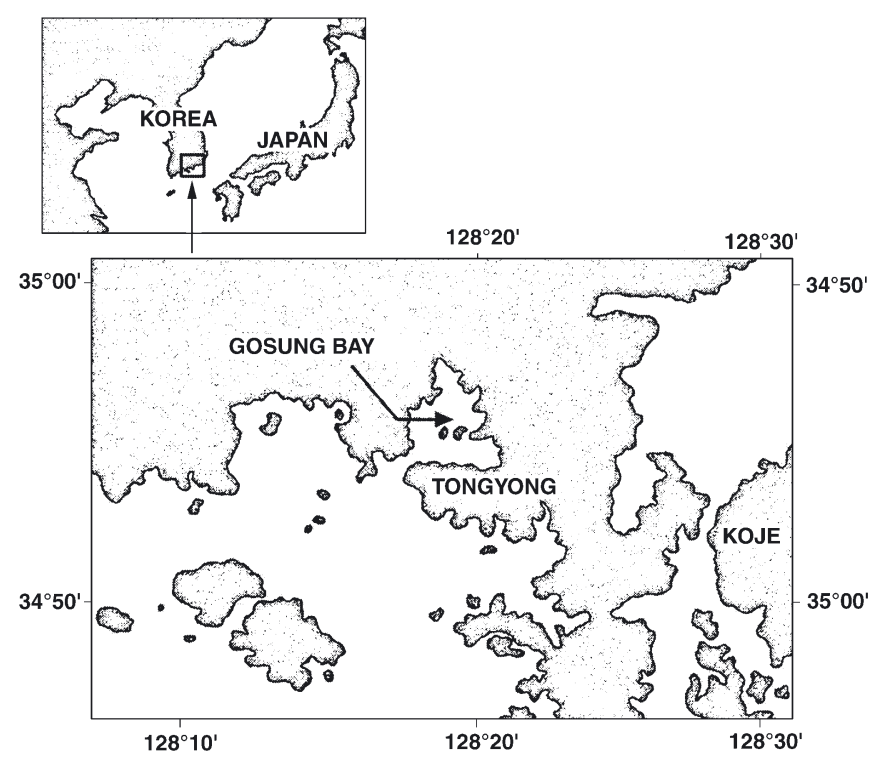

Fig. 1. Location of Gosung Bay, southern coast of Korea
The objectives of this study were to investigate seasonal variation in reproduction of the Crassostrea gigas population in suspended culture systems in Gosung Bay, Korea, and describe the prevalence and infection intensity of Marteilioides chungmuensis parasitism concomitant with the reproductive activity of oysters.

\section{MATERIALS AND METHODS}

Study area and sampling. Gosung Bay is located on the south coast of Korea, where several semi-enclosed bays and islands are located (Fig. 1). The bay has a surface area of $2165 \times 10^{4} \mathrm{~m}^{2}$ with an average depth of $7 \mathrm{~m}$. In this bay, oysters are cultured intensively by suspending oyster ropes hanging from longlines. In the year 2000, 16230 metric tonnes of oysters (including shells) were produced from Gosung Bay; this represents $10 \%$ of the total oyster production in Korea.

For analysis, adult oysters with a shell length over $7 \mathrm{~cm}$ were collected from 3 different sampling locations in Gosung Bay. At each sampling site, a suspended oyster line was randomly selected, and oysters were collected from 2 depth intervals - the surface layer ( 0 to $2 \mathrm{~m}$ ) and the bottom layer ( 3 to $5 \mathrm{~m}$ ). Sampling was monthly from January to December 2000, and biweekly from June to August to follow spawning activity. In situ water temperature and salinity were recorded at each sampling. In the laboratory, the shell length $(\mathrm{mm})$ size of the oysters was measured with Vernier calipers. The oyster tissues were then removed from the shell and wet tissue weight was determined after removing excessive water with absorbent tissue paper.

For histology, 15 to 20 oysters were collected from each of the 2 depth intervals. A transverse cut was made in the middle of the oyster body, and a $3 \mathrm{~mm}$ thick section extracted and fixed in Bouin's solution. Tissue samples were then dehydrated in an ethanol series of progressively increasing concentrations, cleared in xylene, and embedded in paraffin. Serial sections, $4 \mu \mathrm{m}$ thick, were obtained with a rotary microtome and stained with Harris' hematoxylin and eosin Y.

Gonad development and diagnosis of Marteilioides chungmuensis. Gonad development of each oyster was categorized into 1 of 5 stages using a numerical code based on the microscopic appearance of the gonad tissues that was modified from the stage designations of Heffernan et al. (1989), Rose et al. (1990) and Powell et al. (1993)-Stage 1: undifferentiated; Stage 2: developing; Stage 3: ripe; Stage 4: spawning; Stage 5: spent. Gonadal index (GI), a monthly mean of the numerical staging code of the oysters, was then 
calculated for each sampling period to follow cyclic changes in the reproductive tissues. Since no time lag was observed in gonadal maturation between male and female oysters, the numerical codes of the females and males of each month were combined for calculating GI.

Prevalence and infection intensity of Marteilioides chungmuensis were determined by examining the gonad slides under a light microscope according to Park \& Chun (1989). The infection intensity of each oyster was then rated according to Villalba et al. (1993), i.e. 0: no infection (no parasite was detected in entire microscopic field); 1: light infection (parasites were confined to follicle wall or occurred in primary oocytes); 2 : moderate infection (only part of the gonad occupied by the parasite); 3 : heavy infection (whole gonad infiltrated by $M$. chungmuensis). Because of insufficient female oysters per depth category, oysters collected from the 2 depth intervals were combined into 1 sampling unit for further analysis.

\section{RESULTS}

\section{Environmental conditions}

Monthly mean water temperature and salinity for the 2 depth intervals of the suspended longline are presented in Fig. 2. Water temperature in the surface layer varied seasonally from $4.3^{\circ} \mathrm{C}$ (February) to $30.4^{\circ} \mathrm{C}$ (July), while at 3 to $5 \mathrm{~m}$ depth it varied from $4.2^{\circ} \mathrm{C}$ (February) to $26.6^{\circ} \mathrm{C}$ (August). There was a strong stratification of water temperature between the surface and

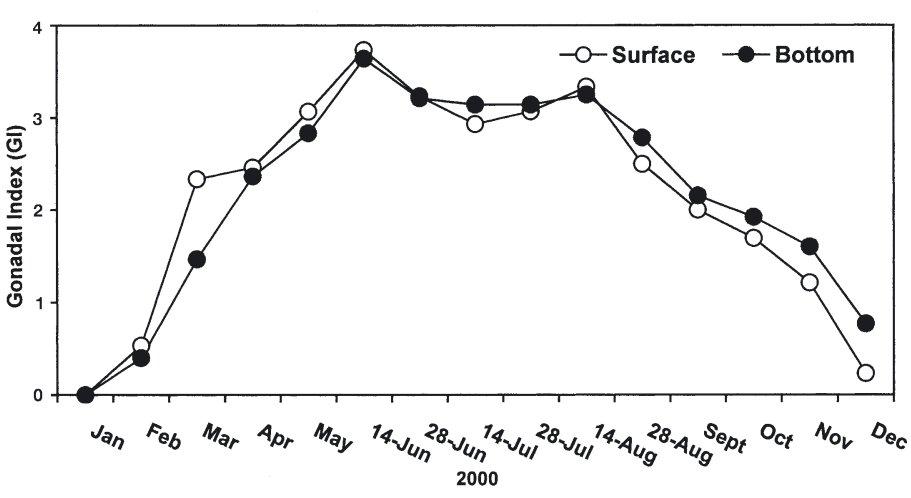

Fig. 3. Crassostrea gigas. Seasonal variation in gonad index of oysters collected from 2 different depth intervals during year 2000 at Gosung Bay. Surface: 0 to $2 \mathrm{~m}$; Bottom: 3 to $5 \mathrm{~m}$

the bottom of the oyster lines in the Bay from April to September. Maximum salinities of 34.3 and $34.2 \%$ were recorded in May in the surface layer and in the 3 to $5 \mathrm{~m}$ layer respectively. From late June to early July, salinity of the surface layer dropped abruptly from 34.0 to $27.6 \%$ due to a large freshwater inflow into the Bay caused by the seasonal monsoon. In contrast, salinity dropped less dramatically in the 3 to $5 \mathrm{~m}$ depth layer from June to July (from 34.0 to $32.3 \%$ ).

\section{Seasonal changes in reproductive condition}

Seasonal changes in GI for the 2 depth intervals at which oysters were collected are summarized in Fig. 3. In Gosung Bay, gametogenesis of oysters started as early as January, when water temperatures reached $8.0^{\circ} \mathrm{C}$. The GI of oysters in the surface layer increased rapidly from February to April as the

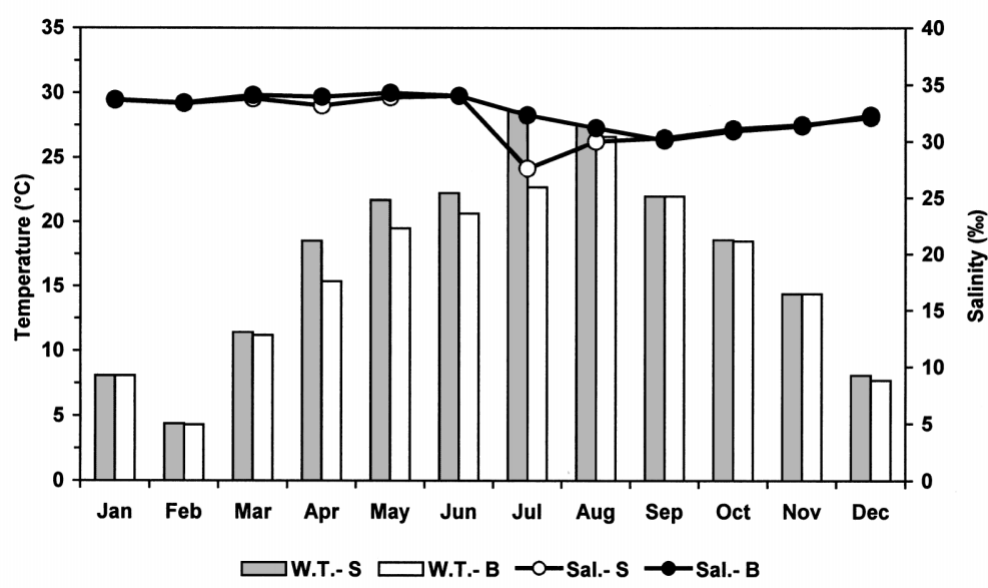
surface water temperature rose from 4.4 to $18.5^{\circ} \mathrm{C}$. The first major spawning of oysters was observed in mid-June regardless of depth, when water temperatures reached 20.7 to $22.3^{\circ} \mathrm{C}$. A second spawning was also observed in late August, although its intensity was somewhat lower than the peak in mid June. The GI declined dramatically from late August to September and October as the surface water temperature dropped from 27.5 to $18.5^{\circ} \mathrm{C}$. Sexually undifferentiated oysters were dominant during December and February at all depths (Table 1).

The effect of culture depth on gonad development of the oysters was obvious at an early stage of gonad development; gonad maturation of oysters in the bottom water layer was slower than that of oysters in the surface layer (Fig. 3). From March to May, when most oysters progressed from the early develop- 
Table 1. Crassostrea gigas. Percentage composition of various development stages of oysters collected from January to December 2000 from 2 depth intervals in Gosung Bay, Korea

\begin{tabular}{|c|c|c|c|c|c|c|c|c|c|c|c|c|c|c|c|}
\hline \multirow[t]{2}{*}{ Gonad stages } & \multicolumn{15}{|c|}{ Sampling period } \\
\hline & Jan & Feb & Mar & Apr & May & 14 Jun & $28 \mathrm{Jun}$ & $14 \mathrm{Jul}$ & $28 \mathrm{Jul}$ & 14 Aug & $28 \mathrm{Aug}$ & Sep & Oct & Nov & Dec \\
\hline \multicolumn{16}{|l|}{ Surface ( 0 to $2 \mathrm{~m}$ ) } \\
\hline Undifferentiated & 100 & 73.3 & & & & & & & & & & & & & 76.9 \\
\hline Developing & & 26.7 & 66.7 & 53.8 & 6.7 & & & & & & & & & & \\
\hline Ripe & & & 33.3 & 46.2 & 80.0 & 26.7 & 30.8 & 46.7 & 50.0 & 41.7 & 25.0 & & & & \\
\hline Spawning & & & & & 13.3 & 73.3 & 53.8 & 33.3 & 35.7 & 50.0 & 33.3 & 33.3 & 23.1 & 7.1 & \\
\hline Spent & & & & & & & 15.4 & 20.0 & 14.3 & 8.3 & 41.7 & 66.7 & 76.9 & 92.9 & 23.1 \\
\hline \multicolumn{16}{|l|}{ Bottom (3 to $5 \mathrm{~m}$ ) } \\
\hline Undifferentiated & 100 & 80.0 & 26.7 & & & & & & & & & & & & 23.1 \\
\hline Developing & & 20.0 & 73.3 & 63.6 & 16.7 & & & 21.4 & & & 7.1 & & & & \\
\hline Ripe & & & & 36.4 & 83.3 & 35.7 & 35.7 & 42.9 & 42.9 & 25.0 & 21.4 & & & & \\
\hline Spawning & & & & & & 64.3 & 50.0 & 14.3 & 42.9 & 58.3 & 42.9 & 38.5 & 30.8 & 20.0 & \\
\hline Spent & & & & & & & 14.3 & & 14.3 & 16.7 & 28.6 & 61.5 & 69.2 & 80.0 & 76.9 \\
\hline
\end{tabular}

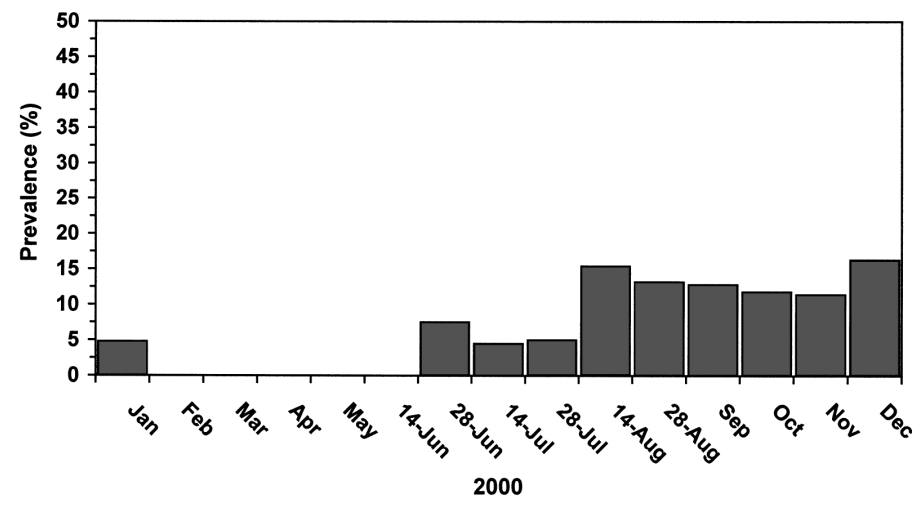

Fig. 4. Crassostrea gigas. Prevalence of Marteilioides chungmuensis in oysters during year 2000

ment stages to fully mature, the monthly mean GI of oysters in the bottom layer was somewhat lower than that of oysters in the surface layer, indicating that gonad development in the bottom layer is slower. Despite the different gonad development rate between oysters in the bottom and surface layers, spawning activity was fairly synchronized in the 2 different depth intervals during the first spawning peak in June, when water temperature in the surface layer was approximately $2^{\circ} \mathrm{C}$ higher than in the bottom water layer.

\section{Occurrence of Martelioides chungmuensis}

In the year 2000, 40 of 608 (7\%) oysters collected from Gosung Bay were infected with Martelioides chungmuensis. Highest prevalence was recorded in December $(16.3 \%)$; no infection was observed from February to early June (Fig. 4). There was very low correlation between the infection prevalence of the parasite and the mean GI of oysters at both depth intervals over the yearly cycle $\left(R^{2}=0.0208\right)$. The infection was limited to female oysters, and the gonad was the only tissue targeted. The prevalence of $M$. chungmuensis in the various reproductive stages is summarized in Fig. 5. In a total 40 of infected oysters, low prevalence was observed in the developing (15\%) and ripe $(10 \%)$ stages, with higher prevalence in the spawning (35\%) and spent (40\%) stages. Fig. 6 shows seasonal changes in the infection intensity of $M$. chungmuensis in female oysters. Infection intensity was high in late June (intensity rate $=2.0$ ) when most oysters were spawning, and also high in mid August (rate $=2.0$ ) and November (rate $=2.0$ ) when some oysters were still spawning or were spent. There was no clear correlation between infection intensity and the mean GI of the observed oysters at both depth intervals $\left(\mathrm{R}^{2}=0.0023\right)$.

Histological sections of the oyster gonad revealed different developmental stages of Martelioides chungmuensis. Several different vegetative stages, including 1 or more secondary cells were observed within folli-

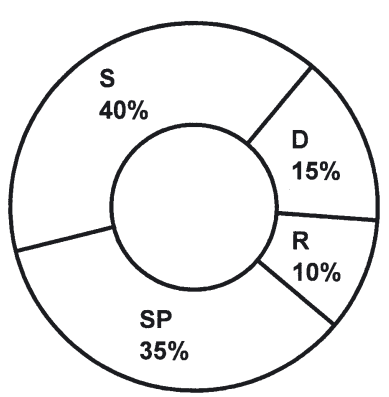

Fig. 5. Crassostrea gigas. Prevalence of Marteilioides chungmuensis in various reproductive stages of oysters. D: developing; R: ripe; SP: spawning; S: spent 


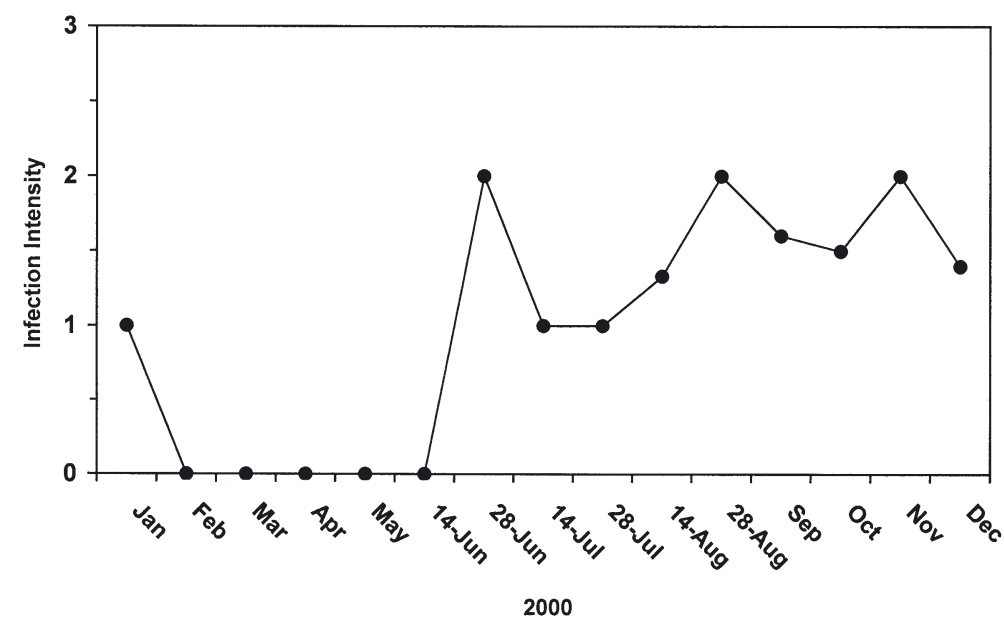

Fig. 6. Crassostrea gigas. Infection intensity of Marteilioides chungmuensis from January to December 2000 in oysters from Gosung Bay. (See last paragraph of 'Materials and methods' for explanation of Intensity Rates 0 to 3)

cles (Fig. 7). Heavily infected oysters often exhibited large accumulations of hemocytes within or around the follicle wall. $M$. chungmuensis displaying 2 to 4 nuclei, 10 to $20 \mu \mathrm{m}$ in diameter, were also found in fully mature eggs (Fig. 8). Some female oysters, collected from November to January, exhibited fully mature intact eggs in their follicles when almost all oysters in this period were reproductively inactive. These infected female oysters exhibited several lump-like egg masses in their mantle, a typical sign of $M$. chungmuensis infection.

\section{DISCUSSION}

Water temperature and food availability in the water column are the 2 main environmental parameters that regulate the reproductive process of oysters; water temperature accelerates or retards the rate of gonad development while food availability mainly determines the quality and quantity of reproductive output (Hayes \& Menzel 1981, Soniat \& Ray 1985, Hofmann et al. 1992, Choi et al. 1994, Kang et al. 2000). Previous studies on gonad development of Crassostrea gigas in small bays on the southern coast of Korea have suggested that cyclic changes in the reproductive condition of oysters follow seasonal changes in water temperature and food supply in the water column (Bae \& Han 1998, Kang et al. 2000, Hyun et al. 2001).

Our data have shown that a few oysters collected in May spawned when the water temperature reached $20^{\circ} \mathrm{C}$. As Kang et al. (2000) suggested, water temperature over 18 to $20^{\circ} \mathrm{C}$ could be the minimum required to induce spawning in Crassostrea gigas in this area, with major spawning events occurring at water temperatures between 23 and $25^{\circ} \mathrm{C}$ in both depth intervals. The spawning activity of oysters in Gosung Bay continued from May to September, when the seawater temperature exceeded $20^{\circ} \mathrm{C}$ throughout the water column. Such continuous spawning of oysters in summer has also been reported from several studies along the bays of the southern coast of Korea (Bae \& Han 1998, Park et al. 1999a,b).

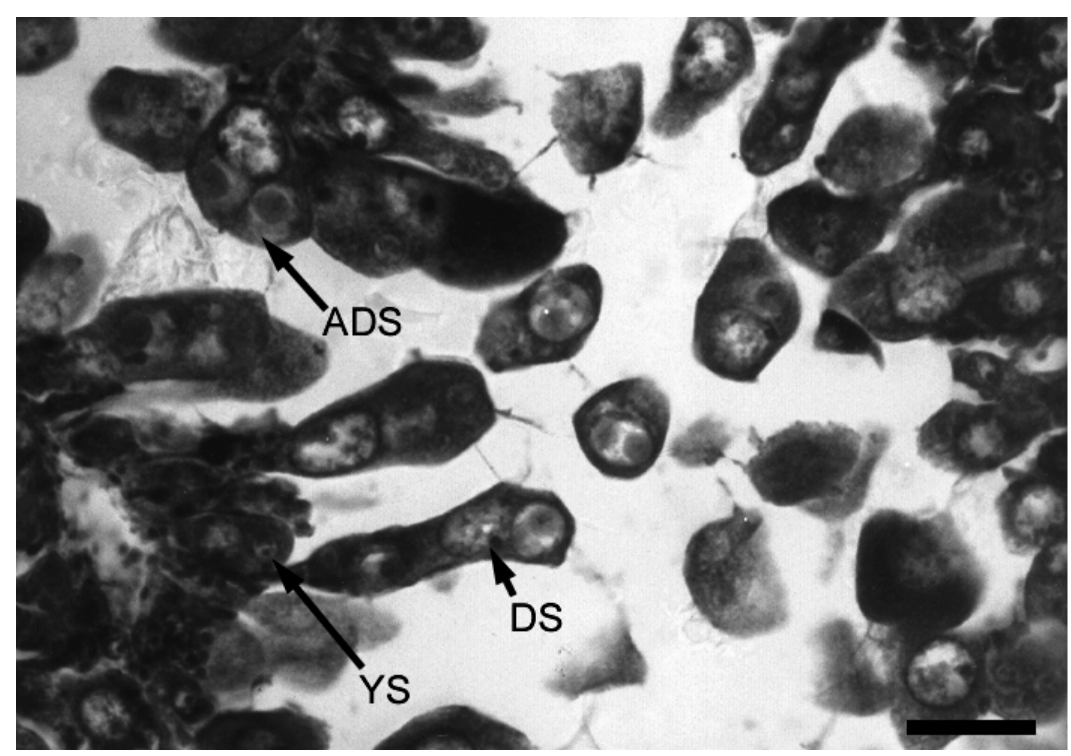

Fig. 7. Marteilioides chungmuensis. Different stages of parasite in oyster gonad. YS: young stage; DS: developing stage; ADS: advanced developmental stage. Scale bar $=50 \mu \mathrm{m}$ 


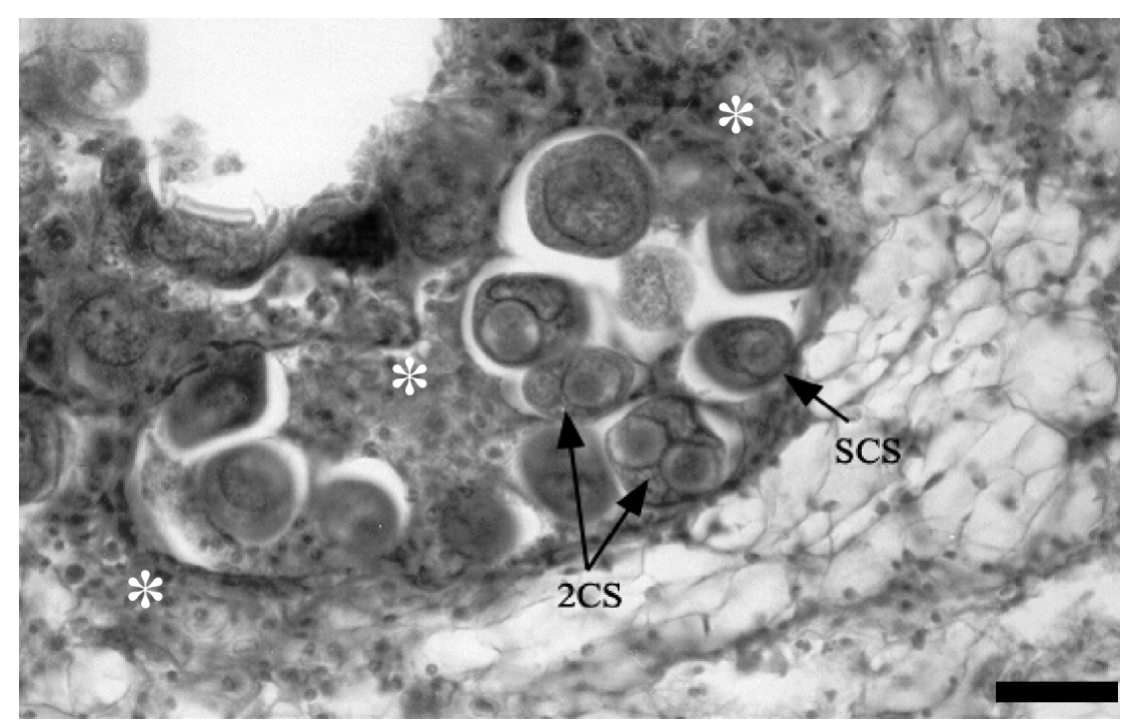

Fig. 8. Marteilioides chungmuensis. Different life stages of parasite present in mature oocytes of Crassostrea gigas. SCS: singlecelled stage; 2CS: 2-celled stage; $*$ : hemocyte infiltration. Scale bar $=50 \mu \mathrm{m}$

Fig. 2 indicates that water temperature in the water column was stratified from the surface to the bottom from April to July, with surface temperatures 2 to $5^{\circ} \mathrm{C}$ higher than bottom temperatures. This stratification in water temperature could be reflected in the gonad maturation of the oysters. As shown in Table 1, gonad development rate in surface waters was faster than in bottom waters from March to May, indicating that water temperature is one of the crucial factors in gonadal maturation. Synchronous spawning of oysters in June, regardless of depth, could partly be due to a temperature threshold for spawning (Galtsoff 1964, Kang et al. 2000). In June, the water temperature in the bottom layer exceeded $20^{\circ} \mathrm{C}$, high enough to induce spawning although $2^{\circ} \mathrm{C}$ lower than the temperature of the surface water layer. Cáceres-Martinez \& Figueras (1998) also found no difference in gonad development of the mussel Mytilus galloprovincialis between 2 and $5 \mathrm{~m}$ depths. Deslous-Paoli \& Heral (1988) demonstrated that seasonal variations in reproductive condition and biochemical composition of the oyster Crassostrea gigas could be affected by cultivation density (i.e. relative food availability), in addition to temperature. Loosanoff (1965) observed that Crassostera virginica living in shallow waters $(3 \mathrm{~m})$ developed much larger quantities of spawn than oysters living at greater depths (6 or $9 \mathrm{~m}$ ). The oysters may have developed more spawn in shallow water because the phytoplankton they use as food were more abundant at that depth. Our study has no data on the relationship between food availability and reproductive effort in oysters from Gosung Bay. However, synchronous spawning and gamete production did not differ signif- icantly as a function of depth. Loosanoff \& Engle (1947) reported that within the depth range of 3 to $9 \mathrm{~m}$, spawning of $C$. virginica began at the same time.

The present study has documented the prevalence and infection intensity of Martelioides chungmuenis over the annual reproductive cycle of oysters in Korea. Interestingly, none of the oysters collected from February to mid June were infected by $M$. chungmuensis (Fig. 4). In contrast, infected oysters were detected continuously from June to February, with the highest prevalence in the fall. Park \& Chun (1989) also reported the prevalence of this parasite in Crassostrea gigas populations in the Hwado and Och'on areas on the south coast of Korea. The degree of infection in the summer and fall seasons was 5.3 and $4.2 \%$ in 1986 , and 6.7 and $2.8 \%$ in 1987 respectively. The prevalence of $M$. chungmuensis in Gosung Bay in the present study in 2000 was as much as $16 \%$, somewhat higher than values reported previously. At Mie, Japan, Imanaka et al. (2001) also observed a high prevalence (18 to $20 \%$ ) from autumn through spring, when oysters completed spawning, as in the present study.

The first incidence of Martelioides chungmuensis in this study occurred in late June, when most oysters were partially spawned or ready for spawning. An earlier occurrence of $M$. chungmuensis in early reproductive stages of oysters cannot be ruled out, since our observation was only based on a light microscopic examination of histological slides. In contrast, Itoh et al. (2002) observed immature stages of $M$. chungmuensis in the lining of follicles, although most parasites occurred in mature ova in the follicle or genital canal of the infected oysters. In this study, it is possible 
that $M$. chungmuensis in early developing ova could have been missed during microscopic examination because of their small size. According to Itoh et al. (2002), the growth of $M$. chungmuensis in Japanese oysters is highly correlated with the maturation stage of oyster ova, with the parasite increasing in diameter and becoming easier to identify in a microscopic field. Consequently, the low prevalence or non-infection recorded in spring could reflect a lack of sensitivity of the microscopic examination, especially in the early stages of the infection. The use of DNA probes during in situ hybridization could clarify this point (Le Roux et al. 1999, Kleeman et al. 2002)

Temperature is considered to be a main parameter governing the life cycle and sporulation process of another paramyxean parasite, Marteilia refringens (Berthe et al. 1998, Audemard et al. 2001). High infection intensity and prevalence of $M$. refringens in European flat oysters Ostrea edulis in France was correlated with high water temperature (Berthe et al. 1998). In the present study, infection intensity of Marteilioides chungmuensis was highest in June (Fig. 5), when water temperature was high, although some oysters collected in December and January, when temperature was as low as $8^{\circ} \mathrm{C}$, exhibited mature eggs infected with the parasite. Our data shows that $M$. chungmuensis can survive at such low water temperatures, as long they are enclosed in the eggs. It is notable that no phagocytosis of these infected ova was observed in oysters collected in winter, while uninfected oyster eggs that remain in normal oysters in winter were phagocytized and absorbed by hemocytes. Perhaps $M$. chungmuensis inhibits phagocytic activity of oyster hemocytes in order to survive in the eggs, although the mechanism has yet to be proven.

Based on microscopic appearance and size, Imanaka et al. (2001) described 8 different life stages of Marteilioides chungmuensis in Crassostrea gigas in Japanese waters, while Itoh et al. (2002) described only 4 life stages. According to Imanaka et al. (2001), $M$. chungmuensis undergoes intracellular divisions in the eggs and progressively moves to the lumen of the genital tubules. However, the life stages proposed by Imanaka et al. (2001) and Itoh et al. (2002) are limited to the stages present inside eggs. The life stage of $M$. chungmuensis in the water column and the mechanism by which it enters the oyster eggs are still unknown. Since $M$. chungmuensis were not observed in oysters in the reproductively inactive stage in February and March, it is postulated that the parasites are distributed in the water column and may enter oysters during the early stages of development in April or May. As gonad development progresses, $M$. chungmuensis grow and reproduce inside the eggs. Infection probably begins in spring, as observed in
Japan, and proceeds through multiplication and sporulation stages during the high water-temperature period from summer to early fall. Stressful environmental conditions such as high temperature and sudden decreases in salinity could weaken the cellular defense activity of oysters and possibly accelerate multiplication of the parasite. The poor physiological condition of oysters after spawning could provide relatively favorable conditions for $M$. chungmuensis, resulting in higher infection intensity and prevalence in late summer and fall. Villalba et al. (1993) also illustrated that high prevalence of a heavy Marteilia refringens infection in mussels Mytilus galloprovincialis is more frequent when pre-spawning and postspawning stages co-occur in a population of mussels. They suggested that $M$. refringens inhibits gonad development of the mussels mainly after spring spawning, and that subsequently the parasite interferes with the metabolic activity of the mussels, resulting in a poor condition index for infected individuals. The massive hemocytic infiltration observed in infected gonads of $C$. gigas in this study suggest that the infected oysters allocate a certain amount of energy to combating the infection. Villalba et al. (1993) demonstrated a negative correlation between $M$. refringens infection and gonad development in mussels they examined. Moreover, Bayne et al. (1982) showed that mussels Mytilus edulis infected by parasites also allocate a high portion of energy to cellular defense mechanisms, resulting in reallocation of their energy reserves.

Acknowledgements. Our thanks to the staff of the Shellfish Aquaculture and Research Laboratory at Cheju National University for their help in sampling and data preparation. We also thank Dr. Chung-Wha Lee Jyenger of the Department of Veterinary Medicine of Cheju National University and anonymous reviewers of this article for their critique, comments and improvement of the English text. T.T.T.N. also thanks the BK 21 Program of College of Ocean Science, Cheju National University for providing research assistantship.

\section{LITERATURE CITED}

Anderson TJ, Lester RJG (1992) Sporulation of Marteilioides branchialis n. sp. (Paramyxea) in the Sydney rock oyster, Saccostrea commercialis: an electron microscope study. J Protozool 39:502-508

Audemard C, Barnaud A, Collins CM, Le Roux F, Sauriau PG, Coustau C, Blachier P, Berthe FC J (2001) Claire ponds as an experimental model for Marteilia refringens life-cycle studies: new perspectives. J Exp Mar Biol Ecol 257:87-108

Bae PA, Han CH (1998) Effects of nursery environmental factors on the growth of Pacific oyster, Crassostrea gigas. Korean J Aquacult 11:391-400 (in Korean with English abstract)

Bayne BL, Bubal A, Gabbott PA, Livingstone DR, Lowe DM, Moore MN (1982) Glycogen utilization and gametogenesis in Mytilus edulis L. Mar Biol Lett 3:89-105 
Becker CD, Pauley GB (1968) An ovarian parasite (Protista incertae sedis) from the Pacific oyster, Crassostrea gigas. J Invertebr Pathol 12:425-437

Berthe CJF, Pernas M, Zerabib M, Haffner P, Thebault A, Figueras AJ (1998) Experimental transmission of Marteilia refringens with special consideration of its life cycle. Dis Aquat Org 34:135-144

Berthe CJF, Le Roux F, Peyretaillade E, Peyret P, Rodriguez D, Gouy M, Vivares C P (2000) Phylogenetic analysis of the small subunit ribosomal RNA of Marteilia refringens validates the existence of phylum Paramyxea (Desportes and Perkins, 1990). J Eukaryot Microbiol 47:288-293

Cáceres-Martínez J, Figueras A (1998) Long-term survey on wild and cultured mussels (Mytilus galloprovincialis Lmk) reproductive cycles in the Ria de Vigo (NW Spain). Aquaculture 162:141-156

Camacho AP, Viallalba A, Beiras R, Labarta U (1997) Absorption efficiency and condition of cultured mussels (Mytilus edulis galloprovincialis Linnaeus) of Galicia (NW Spain) infected by parasites Marteilia refringens Grizel et al. and Mylilicola intestinalis Steuer. J Shellfish Res 16:77-82

Choi KS, Powell EN, Lewis DH, Ray SM (1994) Instantaneous reproductive effort in female American oysters, Crassostrea virginica, measured by a new immunoprecipitation assay. Biol Bull (Woods Hole) 186:41-61

Choi WJ, Chun YY, Park JH, Park YC (1997) The influence of environmental characteristics on the fatness of Pacific oyster, Crassostrea gigas, in Hansan-Koje Bay. J Korean Fish Soc 30:794-803 (in Korean with English abstract)

Chun SK (1970) Studies on the oyster diseases. 1. Pathogenetic investigation. Bull Korean Fish Soc 3:7-17 (in Korean with English abstract)

Chun SK (1972) Preliminary studies on the sporozoan parasites in oysters on the southern coast of Korea. Bull Korean Fish Soc 5:76-82 (in Korean with English abstract)

Chun SK (1979) Amoeba infection in oyster (Crassostrea gigas). Bull Korean Fish Soc 12:281-285 (in Korean with English abstract)

Comps M, Park MS, Desportes I (1986) Étude ultrastructurale de Marteiliodes chungmuensis n. g., n. sp. Parasite des ovocytes de I'huître Crassostrea gigas Thunberg. Protistologica 22:279-285

Comps M, Park MS, Desportes I (1987) Fine structure of Marteilioides chungmuensis n. g., n. sp. Parasite of the oocytes of the oyster Crassostrea gigas. Aquaculture 67: 264-265

Deslous-Paoli JM, M Heral (1988) Biochemical composition and energy value of Crassostrea gigas (Thunberg) cultured in the bay of Marennes-Oleron. Aquat Living Resour $1: 239-249$

FAO (Food \& Agriculture Organization of the United Nations) (1999) FAO aquculture production statistics. FAO Fish Circ 815:

Figueras AJ, Montes J (1988) Aber disease of edible oysters caused by Marteilia refringens. Am Fish Soc Spec Publ 18: $38-46$

Fuentes J, Viallalba A, Zapata C, Alvarez G (1995) Effects of stock and culture environment on infections by Marteilia refringens and Mytilicola intestinalis in the mussel Mytilus galloprovincialis cultured in Galicia (NW Spain). Dis Aquat Org 46:223-229

Galtsoff PS (1964) The American oyster, C. virginica. Fish Bull US Fish Wildl Ser 64:14-80

Hayes PF, Menzel RW (1981) The reproductive cycle of early setting Crassostrea virginica (Gmelin) in the northern Gulf Mexico, and its implications for population recruitment. Biol Bull (Woods Hole) 160:80-88
Heffernan PB, Walker RL, Carr JL (1989) Gametogenic cycles of three bivalves in Wassaw Sound, Georgia: II. Crassostrea virginica (Gmelin, 1791). J Shellfish Res 8:61-70

Hine PM, Thorn T (2000) A survey of some parasites and diseases of several species of bivalve mollusk in northern Western Australia. Dis Aquat Org 40:67-78

Hofmann EE, Powell EN, Klinck JM, Wilson EA (1992) Modeling oyster populations. III. Critical feeding periods, growth and reproduction. J Shellfish Res 11:399-416

Hyun KH, Pang IC, Klinck JM, Choi KS, Lee JB, Powell EN, Hofmann EE, Bochenek EA (2001) The effect of food composition on Pacific oyster Crassostrea gigas (Thunberg) growth in Korea: a modeling study. Aquaculture 199: 41-62

Imai T, Mori K, Sugawara Y, TamateH, Oizumi J, Itikawa O (1968) Studies on the mass mortality of oysters in Matsushima Bay-III. Pathogenic investigation. Tohoku J Agric Res 19:250-265

Imanaka S, Itoh N, Ogawa K, Wakabayashi H (2001) Seasonal fluctuations in the occurrence of abnormal enlargement of the ovary of Pacific oyster Crassostrea gigas at Gokasho Bay, Mie. Jpn Fish Pathol 36:83-91

Itoh N, Oda T, Ogawa K, Wakabayashi H (2002) Identification and development of paramyxean ovarian parasite in the Pacific oyster Crassostrea gigas. Fish Pathol 37:23-28

Kang CK, Park MS, Lee PY, Choi WJ, Lee WC (2000) Seasonal variations in condition, reproductive activity, and biochemical composition of the Pacific oyster, Crassostrea gigas (Thunberg), in suspended culture in two coastal bays of Korea. J Shellfish Res 19:771-778

Kleeman SN, Adlard RD, Lester RJG (2002) Detection of the initial infective stages of the protozoan parasite Marteilia sydneyi in Saccostrea glomerata and their development through to sporogenesis. J Parasitol 32:767-784

Lee MK, Cho BY, Lee SY, Kang JY, Joeng HD, Huh SH, Huh MD (2001) Histopathological lesions of Manila clam, Tapes philippinarum, from Hadong and Namhae coastal areas of Korea. Aquaculture 201:199-209

Le Roux F, Audermard C, Barnaud A, Berthe F (1999) DNA probes as potential tools for the detection of Marteilia refringens. Mar Biotechnol 1:588-597

Loosanoff VL (1965) Gonad development and discharge of spawn in oysters of Long Island Sound. Biol Bull (Woods Hole) 129:547-561

Loosanoff VL, Engle JB (1947) Accumulation and discharge of spawn by oysters living at different depths. Biol Bull (Woods Hole) 87:413-422

Matsusato T, Masumura K (1981) Abnormal enlargement of the ovary of oyster, Crassostrea gigas (Thunberg) by an unidentified parasite. Fish Pathol 15:207-212

Oh KH, Pang IC, Hofmann EE, Kim Y, Kim SY, Park YJ, Choi KS (2002) Modeling oyster populations dynamics. I. Effect of available food on growth of the Pacific oyster, Crassostrea gigas in Gosung, Korea. J Korean Fish Soc 35: 327-335 (in Korean with English abstract)

Park MS, Chun SK (1989) Study on Marteilioides chungmuensis Comps et al. 1986 parasite of the Pacific oyster, Crassostrea gigas Thunberg. Korean J Fish Pathol 2:53-70 (in Korean with English abstract)

Park MS, Lim HJ, Jo Q, Yoo JS, Jeon MJ (1999a) Assessment of reproductive health in the wild seed oysters, Crassostrea gigas, from two locations in Korea. J Shellfish Res 18:445-450

Park MS, Lyu HY, Lee TS (1999b) Investigation on the cause of bad natural seed collection of the Pacific oyster, Crassostrea gigas: relationships between the conditions of mother shell and the viability of the released eggs and 
larvae based on the pathological and embryological survey. J Korean Fish Soc 32:62-67 (in Korean with English abstract)

Powell EN, Wilson-Ormond EA, Choi KS (1993) Gonadal assay-Crasssostrea virginica. NOAA Tech Memo NOS ORCA 71:55-62

Renault T, Cochennec N, Chollet B (1995) Marteiliosis in American oysters Crassostrea virginica reared in France. Dis Aquat Org 23:161-164

Rose RA, Dybdahl RE, Harders S (1990) Reproductive cycle of the Western Australian silver-lip pearl oyster Pintada maxima (Jameson) (Mollusca: Pteriidae). J Shellfish Res 9: 261-272

Editorial responsibility: Albert Sparks,

Seattle, Washington, USA
Soniat TM, Ray SM (1985) Relationships between possible available food and the composition, condition and reproductive state of oysters from Galveston Bay, Texas. Contrib Mar Sci 28:109-121

Ventilla RF (1984) Recent developments in the Japanese oyster culture industry. Adv Mar Biol 21:1-57

Villalba A, Mourelle SG, Carballal MJ, Lopez MC (1993) Effects of infection by the protistan parasite Marteilia refringens on the reproduction of cultured mussels Mytilus galloprovincialis in Galicia (NW Spain). Dis Aquat Org 17:205-213

Wolf PH (1977) An unidentified protistan parasite in the ova of the blacklipped oyster, Crassostrea echinata, from northern Australia. J Invertebr Pathol 29:244-246

Submitted: June 11, 2002; Accepted: April 20, 2003

Proofs received from author(s): August 27, 2003 